\title{
TEMAT SŁOWIAŃSKI W TWÓRCZOŚCI LITERACKIEJ I PRZESŁANIU PASTORALNYM KAROLA WOJTYŁY - JANA PAWŁA II
}

Tytuł tego szkicu zapowiada dwoistość podjętej problematyki oraz jej pograniczność wynikającą z dwóch odmiennych nurtów pozostawionego dzieła i dwóch różnych ról autora w historii literatury, Polski, Europy i świata. Role te są niewspółmierne: $\mathrm{z}$ jednej strony na poły anonimowy poeta ukrywający swoją tożsamość za zmieniającymi się pseudonimami (Andrzej Jawień, Piotr Jasień, Stanisław Andrzej Gruda), z drugiej - kapłan, krakowski arcybiskup, a od października 1978 roku papież, człowiek sprawujący przez kolejnych 27 lat najwyższą godność w Kościele katolickim. Te dwa wymiary znalazły wyraz w życiu i dziele tej samej osoby, więc pytanie o ich wspótistnienie i współzależność nieustannie pojawia się w horyzoncie refleksji autorów biografii i interpretatorów pism Jana Pawła II. Do stawiania takich pytań zachęcał zresztą sam Autor, sugerując, że i dla niego powiązanie tych dwóch ról dotyka tajemnicy życiowego powołania.

Można więc stawiać sobie pytanie: w jaki sposób te dwa powołania: kapłańskie i poetyckie, współistnieją z sobą, w jaki sposób wzajemnie się przenikają w tym samym człowieku? Pytanie takie dotyczy czegoś więcej niż utworów. Dotyczy sprawy, która jest osobistą tajemnicą każdego z nich. Czy jednak pisząc, nie odsłaniają tej tajemnicy? (Wojtyła, „Słowo wstępne” 5)

Poezja była początkiem i punktem wyjścia twórczości pisarskiej Karola Wojtyły/ Jana Pawła II, ale dosyć wcześnie stała się nurtem pobocznym, glosą, może także - pisarskim laboratorium dzieł ważniejszych, utrwalających przesłanie teologiczne

Prof. dr hab. Grażyna Halkiewicz-SoJAK - Katedra Edytorstwa i Literatury Polskiej w Instytucie Literaturoznawstwa UMK; adres do korespondencji: Uniwersytet Mikołaja Kopernika w Toruniu, Fosa Staromiejska 3, 87-100 Torun, e-mail: grahas@umk.pl. ORCID: http://orcid.org/0000-0003-4622-7529. 
i pastoralne kapłana. Tutaj, zgodnie z rytmem biografii Autora, znajdzie się ona w centrum uwagi; spróbuję odpowiedzieć na pytanie, czy w młodzieńczej poezji przyszłego papieża można znaleźć zapowiedź późniejszego nauczania skierowanego do narodów naszej części Europy.

Recepcja utworów literackich Karola Wojtyły wiąże się z dwoma paradoksami. Jego wiersze i dramaty, rozsiane $\mathrm{w}$ numerach czasopism archiwizowanych w bibliotekach lub pozostawione $\mathrm{w}$ rękopisach podarowanych niegdyś przyjaciołom, przez dziesięciolecia pozostawały w ukryciu i zapomnieniu. Do żywego literackiego obiegu wprowadziła je w 1980 roku edycja przygotowana przez Marka Skwarnickiego i Jerzego Turowicza (Poezje i dramaty). W ten sposób Autor został „zdekonspirowany” (Maciejewski 117), a jego poezja dopełniła historycznoliteracką mapę literatury XX wieku. Krzysztof Dybciak uważa, że ta sytuacja wpłynęła na wyraźne wyodrębnienie dwóch „szkół interpretacji”: nurtu skierowanego na analizę i interpretację dzieła oraz nurtu stawiającego w centrum uwagi osobę Autora („Wprowadzenie” 13). Taka klasyfikacja dobrze służy wstępnemu zarysowaniu rozmaitości kierunków badawczych, ale też odsłania opór, jaki pisarstwo Karola Wojtyły stawia interpretatorom. W perspektywie immanentnej lektury nieuchronnie pojawia się kontekst komparatystyczny i to nie tylko literacki, ale także potrzeba wyjścia ku myśli teologicznej, historiozoficznej czy teatrologicznej. Liryka i dramaty kierują uwagę ku osobie Autora nie tylko w perspektywie biografistyki, ale także ze względu na jego role jako kapłana i filozofa - ku bliskim mu nurtom filozoficznym. Bogactwo myśli i nadmiar skojarzeń pisarza często rozbija interpretacyjne założenia czytelników i badaczy.

Drugi paradoks wiąże się z odwróconą chronologią recepcji tej twórczości literackiej. Najwcześniej napisane i zachowane juwenilia powstały w latach 1938-1939, zanim ich Autor odkrył i zaakceptował swoje kapłańskie powołanie, a trafiły do rąk czytelników, we w miarę kompletnym zestawie, sześćdziesiąt lat później (tom z 1980 roku zawierał bowiem, z woli Autora, bardzo ograniczony wybór młodzieńczych utworów). Jan Paweł II obchodził wówczas dwudziestolecie swojego pontyfikatu, rozpoczynał czas podsumowań nie tylko własnego życia i posługi dla Kościoła i świata, ale także - czas oceny duchowej kondycji mijającego stulecia oraz refleksji nad testamentem skierowanym ku przyszłości nadchodzącego wieku. Za naturalne można by uznać, że w tych okolicznościach trafiają do czytelników raczej senilia niż juwenilia. Stało się jednak inaczej; publikacje przygotowane przez Stanisława Dziedzica, Marka Skwarnickiego i Jacka Popiela ${ }^{1}$ kierowały uwagę przede wszystkim ku początkom duchowej i artystycznej drogi Autora. Te początki coś istotnego wszakże wyjaśniały - rzucały nowe światło na wątki myśli, których rozpoznanie

\footnotetext{
${ }^{1}$ W 1995 roku.
} 
wcześniej utrudniały interpretatorom niepełne lub niedostępne ogniwa pisarskiej drogi Karola Wojtyły. Dawali temu wyraz zwłaszcza ci czytelnicy, którzy nie byli skrępowani rygorami akademickiej poetyki a współtworzyli gospodarstwo polskiej literatury. Na przykład Tomasz Burek w zapiskach Dziennika kwarantanny po lekturze Renesansowego psałterza (Księgi stowiańskiej) zanotował:

Można by [...] mylnie wnosić, że chodzi w Sonetach o banalne „,igrzysko rymów”, gdy tymczasem chodzi o objawienie Prawdy, na początek „może nie prawdy świata”, zastrzega się Autor gdzie indziej, ale prawdy duchowych co najmniej widzeń; gdy chodzi o przeciwstawienie się, wyobraźnią i umysłem, czynnikom światowego rozprzężenia, o przeformułowanie syntezy ideowej epoki, o wyznanie wiary i o tajemnicę profetycznej inspiracji wreszcie. (Burek 175)

Diarysta zakończył tę notatkę, datowaną 7 października 1998 roku, pytaniem: „Zaczynem dwudziestu lat pontyfikatu Jana Pawła II byłyżby one poezje «słowiańskiego trubadura»"? (Burek 175). Do tej kwestii powrócił cztery dni później i po przytoczeniu epilogowego fragmentu Renesansowego psalterza, tak podsumował refleksje zrodzone nad lekturą papieskich juweniliów:

Czyśmy słuchali? Czyśmy przez wszystkie te lata dobrze słuchali głosu poety, myśliciela, pontifexa? Ja? Ty? My? Retoryczne pytanie. Ze wstydu spuściłem oczy [...]. (Burek 177)

Czesław Miłosz, po przeczytaniu juweniliów Karola Wojtyły i jego listów do Mieczysława Kotlarczyka, po raz kolejny podkreślił, że twórczość Papieża jest „triumfem polskiego romantyzmu" (Miłosz, Prywatne obowiazki; Miłosz, Rok myśliwego). I chociaż uważał, że nie spełnił się on jako poeta, to uznał, iż ,jego wiersze zdają się przygotowaniem do olbrzymiej działalności pisarskiej, jaką są kolejne encykliki'" - warte czytania i studiowania (Miłosz, „O autonomii”).

Temat słowiański postrzegano jako ważny we wczesnej twórczości Karola Wojtyły nawet wówczas, gdy publikacje z tego okresu były dostępne w skromnym wyborze (Maciejewski; Szymański). Zainteresowanie nim z jednej strony rosło w miarę publikacji nieznanych wcześniej źródeł, z drugiej - nie było jednak szerzej manifestowane. W atmosferze intelektualnej przełomu wieków wątek ten wywoływał pewną konsternację, okazywał się niewygodny. Sytuował się bowiem w kontrze do głównych tendencji w literaturze i humanistyce po 1989 roku. W polskim piśmiennictwie dominował wówczas nurt podkreślający przynależność polskiej kultury wyłącznie do tradycji zachodniej i przekonanie, że jako peryferyjny obszar Zachodu musimy imitować konwencje, idee i metodologiczne mody, by dowieść, że jesteśmy właśnie stamtąd. Oryginalność narodowej literatury, zwłaszcza romantycznej, często

\footnotetext{
${ }^{2}$ Z kontekstu wynika, że Burek pisał po lekturze tomu opracowanego przez Stanisława Dziedzica.
} 
bywała w tym kontekście traktowana nie jako bogactwo, ale jako przeszkoda. Dlatego powtarzały się gesty odrzucania romantycznego paradygmatu (Janion, „Kres paradygmatu") w imię idei liberalnego indywidualizmu, pragmatyzmu, sprzeciwu wobec kanonu narodowej kultury. Atakowano zwłaszcza mesjanistyczne centrum polskiej myśli i symboliki romantycznej, ośmieszano patetyczny wymiar „wielkich słów”, podkreślano anachronizm tyrtejskiego tonu w poezji. A te wszystkie pierwiastki były wyraźnie obecne w młodzieńczej liryce Wojtyły. To, co ewentualnie z tradycji romantycznej i jej estetycznych jakości starano się ocalić, wiązało się z melancholijną refleksją egzystencjalną i poetyckimi świadectwami rozziewu między marzeniami a rzeczywistością.

Tymczasem „słowiańskość” we wczesnej twórczości przyszłego papieża łączy się z manifestowaniem witalności i młodzieńczej energii, z zachwytem urodą świata natury i pięknem sztuki, z deklaracją stawienia czoła dziejowym wyzwaniom. Koresponduje raczej z wezwaniami Mickiewiczowskiej Ody do młodości niż z melancholijnymi skargami romantycznego dziecięcia wieku. Współgra z licznymi dziełami literatury polskiej i z motywami biblijnymi, nawiązuje do sztuki greckiego antyku i renesansu, do europejskiej klasyki (Dziedzic; Krzemińska; Kozłowska). Dla interpretatora Renesansowego psałterza (Księgi słowiańskiej) kłopotem, z którym musi się zmierzyć, jest wielostronny nadmiar i z jego powodu temat stawia opór uporządkowanej problematyzacji. Spróbuję jednak pokazać główne komparatystyczne linie, ryzykując uproszczenia trudne do uniknięcia wobec takiej materii literackiej. Poszukam odpowiedzi na trzy kluczowe pytania: o kształt i źródła kreacji lirycznego „ja”, o prototeksty, o historiozoficzne idee, które ewokuje obraz świata poetyckiego.

\section{KREACJA LIRYCZNEGO „JA”}

Na strukturę i genologiczną rozmaitość Renesansowego psałterza (Księgi słowiańskiej) wpłynęła w pewnej mierze chronologia powstawania poszczególnych części. Najwcześniej napisane fragmenty: wiersz dedykacyjny poświęcony zmarłej Matce i cykl siedemnastu sonetów tworzył wiosną 1939 roku, dziewiętnastoletni wówczas, student polonistyki; pod swoim lirycznym zbiorem zamieścił notkę: „Skończyłem na Święty Jan 1939" (Wojtyła, Poezje, dramaty, szkice 39). Prozatorski fragment zatytułowany Sonety - zarysy powstał blisko rok później, już w okresie niemieckiej okupacji; jego tematem jest wspomnienie minionej pracy nad wierszami i refleksja nad źródłami sztuki poetyckiej. Zarazem jednak ten krótki, autotematyczny esej pełni funkcję wstępu do cyklu napisanych wcześniej sonetów (Bernacki). O ile w tej części dominują motywy „księgi słowiańskiej” nawiązujące do mitu łagodnej Słowiańszczyzny - krainy bujnej przyrody podpowiadającej śpiewakom i poetom 
melodię ich pieśni, o tyle część psalmiczna jest zapisem już innego doświadczenia. W mniejszym stopniu patronuje jej fascynacja urodą rodzimych pejzaży, chociaż pamięć o nich nadal trwa. Do głosu dochodzi jednak groza historii, w której Poeta próbuje mimo wszystko odnaleźć harmonię i nadrzędny sens. Może dlatego demuzykalizacji świata przeciwstawia manifestacyjnie „muzyczne” formy poetyckie: psalm, hymn, rapsod, ,poemat symfoniczny”.

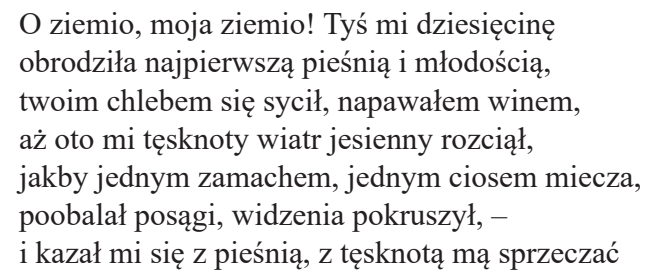

(Wojtyła, Poezje, dramaty, szkice 40)

Te słowa, zapisane jesienią 1939, odsyłają i do biograficznego, i do historycznego kontekstu, ale przede wszystkim próbują uchwycić wewnętrzne, podmiotowe przeżycie. Jest to jeden z wyróżników stylu psalmicznego, ale zarazem ślad obecności odautorskiego ,ja" zanurzonego w konkretnym miejscu i czasie. W lirycznym lustrze młodzieńczych poematów znajdziemy więc odbicie Autora: wcześnie osieroconego przez matkę i naznaczonego tęsknotą, ale z entuzjazmem wędrującego i po beskidzkich ścieżkach, i po meandrach polskiej literatury - od Jana Kochanowskiego, poprzez wielkich romantyków - do Stanisława Wyspiańskiego, Jana Kasprowicza, Emila Zegadłowicza (Burghart; Dziedzic). Celem wędrówki w obydwu wymiarach jest nie tylko poznawanie ich przestrzeni, ale także - odkrywanie śladów Bożej obecności w naturze i w sztuce. Dlatego uniwersalnym przewodnikiem na obu drogach okazuje się biblijne Słowo i poeta sięga po biblijną stylizację lirycznego ,ja”. Już w inicjalnym psalmie czytamy:

Panie, jam Dawid, syn Izai,

Piastowy jestem syn.

Ty mi na sercu znak wypalisz -

zasłucham się w Twój rym.

(Wojtyła, Poezje, dramaty, szkice 28)

Autoprezentacja w pierwszym wersie kojarzy podmiot z królem Dawidem, co nie zaskakuje, skoro Poeta już w tytule utworu nawiązał do formy psałterza, a tradycja właśnie Dawidowi przypisała autorstwo Księgi Psalmów. Intrygujące jest natomiast to, dlaczego Dawid został nazwany „synem Izai”, skoro przekaz biblijny mówi, że był siódmym synem Jessego z Betlejem? (1 Sm 16,1-13). Być może Poeta nawiązał tutaj do starej formy imienia ojca Dawida, użytej w przekładzie Jakuba Wujka 
w Księdze Kronik (po śmierci Saula „Pan przeniósł królestwo jego na Dawida, syna Izaja" - 1 Krn 10,14), a może dzięki skojarzeniu tego imienia z prorokiem Izajaszem chciał też zasugerować, że na mocy duchowego pokrewieństwa wybiera dla siebie rolę dziedzica zarówno Dawida: pasterza-króla-poety, jak i proroka Izajasza. Obie biblijne postacie łączy to, że są antycypacją Chrystusa: pierwszy - w wymiarze ziemskiej genealogii; drugi jako prorok Jego nadejścia i mesjańskiej misji (Iz 11,1-12). Następny wers wprowadza jeszcze inny wymiar duchowej tożsamości pierwszoosobowego bohatera - jest on potomkiem Piasta, spadkobiercą słowiańskiej: ludowej i zarazem królewskiej tradycji. Dwoistość jego statusu społecznego w tym wymiarze została mocno zaakcentowana w charakteryzujących go metaforach. Z jednej strony określają go sformułowania: „Piast - kmieć, oracz” (Wojtyła, Poezje, dramaty, szkice 42), „słowiański trubadur”, „błogosławiony świątkarz, Słowianin i prorok” (65), z drugiej: „,pieśniany władyka” (43), „słowiański karmazyn” (43, 48), ale także słowiański męczennik - „brat” św. Szczepana (70). To tylko przykłady wybrane dla zilustrowania ukrytego w przywołanych określeniach wezwania do pogodzenia słowiańskiego, ludowego dziedzictwa z tradycją szlachecką ukształtowaną w „złotym wieku” polskiego renesansu, a utrwaloną w przekładzie psalmów i w pieśniach Kochanowskiego.

Sposób kształtowania podmiotu, który jest zarazem bohaterem poematu, polega na nakładaniu na jego literacki wizerunek kolejnych warstw tożsamości, ma romantyczny rodowód. Nawiązuje przede wszystkim do dwóch dzieł: Króla-Ducha Juliusza Słowackiego i Promethidiona Cypriana Norwida. Już w pierwszym rapsodzie mistycznego poematu Słowackiego duch zmarłego bohatera o platońskim rodowodzie wciela się w legendarnego władcę ziemi Polan - Popiela, którego dziejowe zadanie będzie polegać na krwawym wprowadzeniu Słowiańszczyzny - przedhistorycznej i sielskiej - w historię.

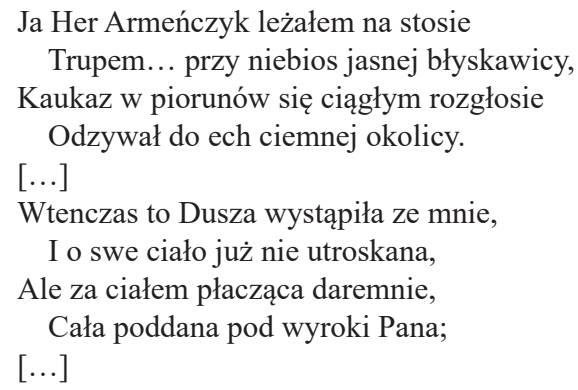

Bohater Słowackiego zostaje wysłany na daleką, szczęśliwą ziemię łąk i lasów, by tam wypełniać swoją okrutną misję. Osobowość „,słowiańskiego trubadura” Woj- 
tyły w niczym nie przypomina oczywiście Popiela, wspólne cechy łączą go z innym bohaterem pierwszego rapsodu Króla-Ducha - z lirnikiem Zorianem. Analogiczny wobec poetyki romantyka jest jednak sposób kreowania postaci $-\mathrm{z}$ jednej strony utożsamionej z lirycznym ,ja”, z drugiej - zmieniającej kostiumy i tożsamości zaczerpnięte z różnych epok. Dzięki temu utwór jest i poematem psychologicznym, którego „akcja” rozwija się w przestrzeni życia wewnętrznego, i dziełem historiozoficznym (Piwińska). Tej podwójnej perspektywy Autor Renesansowego psatterza (Księgi słowiańskiej) nie wprowadza jednak, tak jak Słowacki, za sprawą konceptu metempsychozy, lecz dzięki multiplikacji kulturowych skojarzeń. To z kolei zbliża go przede wszystkim do sposobu kreowania postaci w Norwidowskim Promethidionie (Norwid, Promethidion). Tytułowe i zarazem centralne osoby w poetyckich dialogach tego utworu: Bogumił i Wiesław pełnią role porte-parole autora, ale jednocześnie dzięki intertekstualnym zabiegom zostają wyposażone w symboliczne warstwy kulturowej tożsamości. Bogumił za sprawą sytuacji lirycznej otrzymuje rysy dziewiętnastowiecznego Sokratesa, który rozstrzyga dylematy salonowego dialogu na wzór wzięty z Uczty Platona. Wiesław jest wystylizowany na „gladiatora Prawdy” i proroka (Halkiewicz-Sojak, „Autokreacja”). Na pozór więcej dzieli te osobowe figury niż łączy; każda z nich należy do innej tradycji kulturowej: prorok - izraelskiej i starotestamentowej, Sokrates - greckiej i filozoficznej, gladiator - rzymskiej. Cała triada wskazuje jednak na źródła europejskiej i chrześcijańskiej aksjologii i opartej na niej cywilizacji. W tych źródłach zakorzeniona jest także słowiańska i polska tradycja, co sugeruje już brzmienie i etymologia imion Bogumił i Wiesław. Postacie Sokratesa, proroka i gladiatora łączy w Norwidowskim utworze także to, że każda z nich dopełniała, ale i rozbijała zastygłe formy kultury i płaciła za to męczeństwem. Stawała się ofiarą zapowiadającą nadejście Chrystusa i przełom, który miały przynieść Jego śmierć i zmartwychwstanie. Tę sugestię wzmacnia jeszcze tytuł całości - Promethidion - potomek Prometeusza - męczennika i nauczyciela prac i rzemiosł (Norwid pomija interpretację mitycznego tytana jako buntownika i bogoburcy, popularną w poezji romantycznej). Skojarzenie tych wszystkich postaw zaczerpniętych $\mathrm{z}$ antycznych źródeł i zinterpretowanych przez poetę jako antycypacja chrześcijaństwa, wiąże się z autokreacją i motywem „wiecznego człowieka”. W ten sposób tradycja religii i sztuki staje się składnikiem wewnętrznej biografii podmiotu. Z sięganiem po podobne sposoby poszerzania perspektywy własnej myśli i świata wewnętrznych przeżyć mamy do czynienia także w poetyckich juweniliach Wojtyły - „Sprawy ludzkie szerokie mają brzegi” (Wojtyła, Poezje, dramaty, szkice 112).

Wróćmy do polskiej i słowiańskiej lokalności; bohater Księgi słowiańskiej przedstawia się jako „Piastowy syn” i akcentuje swój dwoisty rodowód: ludowy i królewski. Można w tym dostrzec intencjonalne podjęcie Norwidowskiej refleksji skupionej wokół postaci Piasta i zamysł jej kontynuacji. By tego dowieść, trzeba zatrzymać 
się na chwilę przy motywie Piasta-kołodzieja w pisarstwie Norwida, a jest to tutaj jeden z motywów wędrownych. Nie został wprawdzie nigdzie przez poetę szeroko i epicko rozwinięty, ale pełni w wielu kluczowych miejscach funkcję zwornika myśli, metafory scalającej. Jego doniosłość wynika z tego, że występuje w takiej roli w programowych utworach poety: Promethidionie, Fortepianie Szopena, w IV. i VI. Lekcji o Słowackim. Znajdziemy go także w mniej znanych tekstach: w sztambuchowej fraszce ( $W$ albumie $h r . R$.), w szkicu Piast i jego rewolucja, w Notatkach $z$ historii. We wszystkich przywołaniach piastowskiej legendy Norwid wydobywa na pierwszy plan misję anielskich posłańców, którzy dla rodzącego się narodu przynoszą zaproszenie na ścieżkę historii. Pełnią rolę analogiczną do tej, jaką pełnili boscy wysłannicy, których gościł biblijny Abraham w ziemi Ur. Piast wprowadził naród polski w historię, podobnie jak Abraham naród wybrany. W obydwu przypadkach dokonała się religijna i dziejowa inicjacja. Norwid wydobywa z legendy Piasta-kołodzieja jednak jeszcze inny - mniej oczywisty motyw, który najpełniej rozwija w drugim dialogu Promethidiona w ,wykładzie” Wiesława:

Tu kredą koło zakreślił na stole,

A potem z środka promień wywiódł w kole

I mówił: Środek, który centrum znaczy,

Znaczy i sposób w tym polskim języku,

Który ma w sobie i $w$ ludziach stuchaczy-

Owóż to jeden sposób! - O! Mistyku

Największy, Piaście stary, tyś to wiedział

Od złotowłosych pielgrzymów zza świata...

(Norwid, Promethidion 96)

Anielscy zwiastuni objawiają gospodarzowi technikę i symbolikę koła i jego środka. Poeta uruchamia podwójną semantykę tego ostatniego słowa: 'środek' to i 'centrum', i 'sposób' - źródło metodologii narodowego bycia w świecie historii. Piast staje się w takim kontekście potencjalnym prawodawcą i twórcą społecznego kształtu przyszłej wspólnoty, a to wskazuje analogię nie tylko do Abrahama, ale i do Mojżesza. Jego zadanie wciąż jednak czeka na realizację i to zarówno w Polsce, jak i w całej Europie. Z motywu Piasta wyprowadza poeta w wierszu $W$ albumie $h r . R$. proroctwo przezwyciężenia konfliktu między chrześcijańskim i rycerskim etosem a wartościami demokratycznymi (Halkiewicz-Sojak, Nawiązane ogniwo 193-205)

Bo bez szlachectwa równość nie istnieje,

Ani szlachectwa bez równości nie ma:

Duch wieczny w mrokach staropolskich dnieje

I rozpromienia się skrzydły obiema.

I czasy przyjdą takie, że Europa,

Co tu i owdzie o foremki woła, 
Będzie jak koło kruszwickiego chłopa,

A ramię Boże - jak oś tego koła!

(Norwid, Pisma 1: 181]

Dziedzicem tego proroctwa staje się bohater młodzieńczych utworów Karola Wojtyły, ale czy na pewno tylko wtedy, u progu twórczości; a może zabrzmi ono donośniej także wiele lat później? Jego echo dostrzegł, choć niekoniecznie zaaprobował, Czesław Miłosz, który w Roku myśliwego zanotował:

Legenda o Piaście-oraczu, niebieskookie lnianowłose anioły, cnoty rycerskie, zdziwienie złem świata. U Norwida jest wiara w niepowtarzalną esencję i zapewne w powołanie każdego narodu jako plemienia [...]. Nacjonalizm w sensie formacji historycznej pełniej wyraża się u Norwida niż u Mickiewicza i Słowackiego.

$[\ldots]$

Klęska kraju i klęska osobista Norwida, a tu raptem wciela się on w przywódcę światowego chrześcijaństwa występującego do walki z siłami ciemności. Jest nad czym zastanowić się i zadrżeć. $(36,37)$

Do zasygnalizowanego tutaj wątku powrócę w ostatniej części artykułu.

\section{W POSZUKIWANIU PROTOTEKSTU}

W krytycznoliterackich szkicach i filologicznych studiach poświęconych juweniliom przyszłego papieża wielokrotnie wskazywano bogactwo aluzji literackich i różnorodność komparatystycznych kontekstów (Dybciak, Karol Wojtyła; Seul, Literatura polska). Z kręgu chronologicznie najbliższej tradycji zwracano uwagę na wpływ Emila Zegadłowicza i Mieczysława Kotlarczyka (Maciejewski; Szymański; Dziedzic; Popiel, Los artysty; Popiel, „Karol Wojtyła”). Analizowano intencjonalne gesty odrzucenia pewnych wątków - np. krytyczny dystans wobec twórczości skamandrytów, ale także - analogię z estetycznymi i ideowymi wyborami rówieśników (Urbanowski). Wszyscy interpretatorzy akcentowali znaczenie romantycznych lektur, zwłaszcza Mickiewicza i Norwida, oraz młodopolskiego neoromantyzmu, przede wszystkim dramatów Wyspiańskiego i Hymnów Kasprowicza (Dybciak, Karol Wojtyła; Popiel, „Karol Wojtyła”). W artystycznym stylu utworów odnajdowano ślady fascynacji językiem poezji i retoryki staropolskiej (Kozłowska). Nasuwa się w tym kontekście pytanie, czy któryś ze wskazanych wątków zastanego dziedzictwa literackiego można uznać za nadrzędny i w jego nurcie odnaleźć prototekst Renesansowego psatterza (Księgi stowiańskiej)? Projekt odpowiedzi zarysował się już w trakcie interpretacji podmiotowości i osobowości bohatera lirycznego w poprzednim fragmencie: prototekstów trzeba szukać w kręgu poezji Norwida. Taką rolę poetyckiego wzorca 
wobec młodzieńczego cyklu Wojtyły pełnią dwa utwory: Promethidion i Fortepian Szopena. Oprócz przesłanek wynikających z analizy postaci, argumentów na rzecz takiej tezy dostarczają obserwacje genologiczne.

Gatunkowa forma Promethidiona (1851) była jednym z głównych powodów konfuzji czytelników z połowy XIX wieku, ale i współcześni odbiorcy mają kłopot z jej rozszyfrowaniem. Najtrafniejszą jej formułę znalazł Stefan Sawicki, używając metafory collage'u (Sawicki). Poszczególne, różne gatunkowo i względnie autonomiczne fragmenty są bowiem w utworze raczej zestawione niż harmonijnie zestrojone w jednolitą strukturę. Wprawdzie podtytuł: Rzecz w dwóch dialogach z epilogiem i prozatorska przedmowa Do czytelnika wskazują, że fundamentalnym wzorem struktury genologicznej będzie platoński dialog, ale lektura całości nie w pełni potwierdza tę sugestię. Owszem, znajdziemy nawiązania do filozofii Platona, zwłaszcza do koncepcji platońskich transcendentaliów (Miłości, Prawdy i Dobra), a w centralnych fragmentach (Bogumit, Wiesław) sytuacje rozmówców i dynamika rozmowy przypominają rytm wymiany poglądów w dialogach Platona. Żywioł liryczny przeważa tutaj jednak nad filozoficznym dyskursem, a rozmowa osiąga punkt kulminacyjny w lirycznych monologach. Elementy klasycznej oracji splatają się z cechami romantycznej improwizacji, proroctwa, manifestu artystycznego. W monologu Bogumiła pojawiają się nazwy gatunków jako wyraz autotematycznej refleksji i wskazówka dla odbiorcy (,,i nucąc psalm - sierota!... idę...”, „hymn rozmowy”, „w tym - o pięknem przypowieść ma leży!...”). Dialog platoński splata się z gatunkami biblijnymi, cechy retorycznego traktatu z liryzmem romantycznych improwizacji (Halkiewicz-Sojak, Nawiąane ogniwo 103-115). Podobnie sylwiczny charakter ma Renesansowy psałterz (Księga słowiańska) Wojtyły. Już nawet wiersz dedykacyjny dla bliskiej osoby zmarłej, wychylający się ku formie lirycznego epitafium, zbliża obydwa cykle poetyckie i wskazuje perspektywę, z której każdy z poetów patrzy na ,rzecz ludzką”. W cyklu Wojtyły, wyraźniej niż u Norwida, dominuje żywioł liryczny. Decyduje o tym wybór gatunków: sonetu, psalmu, hymnu, rapsodu, ballady oraz bardziej bezpośrednia ekspresja uczuć i obfita metaforyka związana z motywami przyrody (zwłaszcza drzew, lasu, gór). Natomiast łączy te dzieła rozległość refleksji i fundamentalny charakter egzystencjalnych i historiozoficznych pytań. Rytm myśli i emocji w obydwu przypadkach odzwierciedla doznanie świata, w którym pękają aksjologiczne spoiwa, a wysiłek poszukiwania drogi do ich scalenia i/lub ocalenia determinuje ewokowane idee.

Muzyczność i motywika Renesansowego psałterza wskazują na to, że rolę prototekstu można przypisać nie tylko Promethidionowi, ale także - Fortepianowi Szopena, który jest najgruntowniej bodaj przeanalizowanym wierszem Norwida. Wielość poświęconych mu prac wynika zapewne z tego, że to właśnie w tym po- 
etyckim arcydziele skupiają się najistotniejsze idee i cechy stylistyczne Norwidowskiej poezji (Halkiewicz-Sojak, Nawiazane ogniwo 110). Muzyka jako temat i muzyczność jako cecha stylu poetyckiego są również od początku obecne w cyklu Wojtyły, ale narastają i kulminują w jego finale: w hymnie Magnificat i w poemacie symfonicznym Ballada wawelskich arkad. To właśnie te fragmenty są szczególnie nasycone aluzjami do Norwidowskiego Fortepianu Szopena. Ballada jest kulminacją muzyczności w całym Renesansowym psałterzu (Księdze słowiańskiej). Rodzaje muzyki, którą słyszy i analizuje poeta, umieszcza on na wertykalnej osi.

\section{$[\ldots]$}

Ległem, leżę w bruździe.

Wszedłem w melodię ziemi. U kolan świegot traw.

Otwórzcie tylko drzwi! Kotar rozpuście!

Oto w górze, na słońcach dziewięciu

Dziewięć chórów rozbrzmiewa chwalbą -

A tutaj w lasach kuje dzięcioł,

Tutaj w kalinach chrząszcze brzęczą -

Bóg mówił ze wszystkich ambon.

U dołu tej osi słychać melodię ziemi, transmitowaną na muzykę natury - łąki, lasu, wiatru i przetwarzaną w pieśni ludowej; wyżej rozbrzmiewa pieśń historii, a ponad tym wszystkich rozlega się pitagorejska muzyka sfer, utożsamiana z anielską pieśnią. I to jej harmonijne dźwięki chciałby poeta usłyszeć.

Muzyko! głowy w niebo podnieś!

- że korzeń w ziemię wrósł, to wiem - słuchałem -

Lecz dokąd sięga szczyt - jak dostrzec? -

(Wojtyła, Poezje, dramaty, szkice 69, 70)

Ku temu szczytowi, do którego nie może dotrzeć poetyckie słowo, prowadzi muzyka Chopina; to ona pośredniczy między melodią ziemi - tej konkretnej ziemi - a muzyką Nieba. Wskazują na to aluzje do dzieła kompozytora i przede wszystkim - do Norwidowskiego Fortepianu Szopena. Chociaż biografie Norwida i Wojtyły dzieli stulecie, to obydwaj odnaleźli w tej muzyce ideał i syntezę polskiej i słowiańskiej kultury oraz zapowiedź jej dziejowej misji. By to dokładniej zobaczyć, trzeba wejść w krąg refleksji historiozoficznej autorów. 


\section{W KRĘGU HISTORIOZOFICZNEGO MYŚLENIA}

W centralnym fragmencie Norwidowskiego poematu pojawia się wizja Polski, którą ewokuje muzyka Chopina:

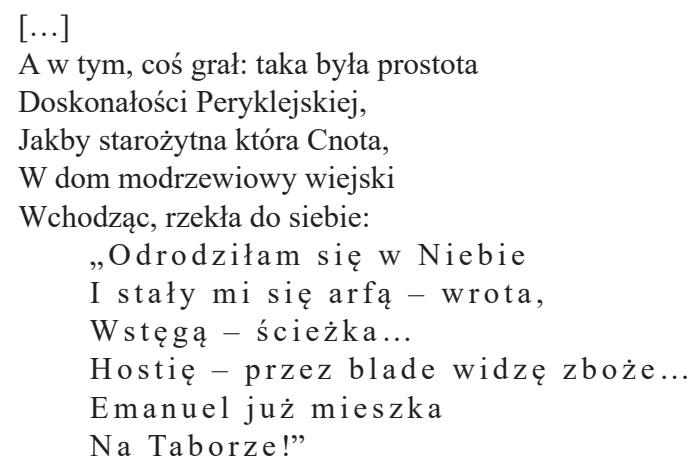

(Norwid, Pisma 2: 144, 145)

Nie jest to opis realnie istniejącej przestrzeni, lecz projekcja ideału, na którym nieuchronnie „zemści się brak”, bo realizacja doskonałości nie jest możliwa w wymiarze czasu historycznego. I finałowe, gwałtowne sceny są w poemacie relacją o tej zemście realności na ideałach. Fortepian, który „głosił” i symbolizował doskonałą „Polskę przemienionych kołodziejów", został rozbity na warszawskim bruku, ale jego pieśń przetrwała, tak jak orfickie hymny, jak muzyka Chopina. Cierpienie, pasja okazały się jeszcze raz ceną za zbliżenie do dopełniającej syntezy.

W Balladzie wawelskich arkad Karol Wojtyła podjął ten wątek i jak gdyby dopisał dalszy ciąg niewidzialnego, a sugerowanego przez muzykę wymiaru dziejów. Po kilkakrotnie powtórzonym motywie uśpionego instrumentu i wzmiance o wygaśnięciu muzyki (,w pianinie zaległ sen, piastowski sen o skowronkach”, ,w pianinie usnął trel" - Wojtyła, Poezje, dramaty, szkice 68), powraca widmo Fryderyka i jego pieśn; budzą ją z uśpienia kolejne już w dziejach „hordy Batuchana” i męczeństwo, które przynosi ich najazd. Apogeum męczeństwa to także moment zenitu muzyki. Cień kompozytora i jego pieśń walczą z przemocą i jej niszczycielskim żywiołem. Walka 
kończy się klęską, tak jak w poemacie Norwida: rozbite pianino moknie w deszczu na stratowanym pobojowisku, widmo Fryderyka runęło na okrwawiony fortepian w wielkiej, pustej sali. Ale właśnie wtedy na scenę ludzkich dziejów wkracza Bóg, by wykuć ich nowy kształt. Wojtyła nie konkretyzuje tak wyraźnie jak Norwid ideału Polski - aluzje do Fortepianu Szopena wskazują przede wszystkim na sielski i ,piastowski” obraz ojczystej ziemi. Wizja Norwida była od razu wielowymiarowa; składała się na nią tradycja grecka (peryklejska sztuka), rzymska (motyw Cnoty), polska (modrzewiowy dom), a wszystkie one - przemienione dzięki objawieniu Chrystusa (motyw Hostii i góry Tabor). U Wojtyły ten wymiar tożsamości jest sugerowany w sposób nieco głębiej ukryty - za pośrednictwem motywu renesansowej architektury (wawelskie arkady) i przywołania postaci pierwszego męczennika św. Szczepana. Wyraźniej została natomiast wyrażona nadzieja na Bożą interwencję.

Obie historiozoficzne wizje są kolejnymi ogniwami romantycznej (poetyckiej i filozoficznej) dyskusji o Słowiańszczyźnie i randze wątku słowiańskiego dla polskiej tożsamości. Temat, zainicjowany u progu XIX stulecia (Klarnerówna), nawiązywał do Herderowskiego wizerunku Słowianina i zapowiedzi przyszłej, wiodącej roli narodów słowiańskich w dziejach Europy (Herder 487-494). Polska dyskusja wokół niego kulminowała w dwóch rozprawach opublikowanych w 1818 roku: Kazimierza Brodzińskiego O klasyczności i romantyczności tudzież o duchu poezji polskiej (Brodziński 1964) oraz Zoriana Dołęgi-Chodakowskiego O Stawiańszczyźnie przed chrześcijaństwem (Dołęga-Chodakowski). Obydwaj autorzy akceptująco nawiązali do wizerunku łagodnego i bliskiego naturze Słowianina, byli też zgodni w ocenie walorów ludowych pieśni i legend jako postulowanych źródeł kultury narodowej. Różniła ich jednak ocena roli, jaką spełniło chrześcijaństwo wobec pogańskiej kultury Słowian. Zdaniem Chodakowskiego, Kościół zniszczył tę organiczną kulturę, narzucając w zamian obcą, która nigdy się w pełni nie zakorzeniła i dlatego nie mogła się stać podstawą harmonijnej organizacji życia społecznego. Brodziński widział tę relację odmiennie: uważał, że Słowianie (lud Słowa) byli predestynowani do przyjęcia ewangelicznych prawd i oczekiwali wartości, które dopełnią intuicje obecne w ich wizji świata. Wskazywał, że to chrześcijaństwo otworzyło drogę wiodącą od plemiennej egzystencji do narodowej historii (Witkowska; Janion, Niesamowita Stowiańszczyzna 5-32). W dziewiętnastowiecznym piśmiennictwie współistnieją polemicznie obie interpretacyjne linie tego problemu, z tym że „linia Brodzińskiego” zyskała wsparcie znamienitszych kontynuatorów: Mickiewicza, Cieszkowskiego, Krasińskiego, Norwida. Trudno ich autorytetowi przeciwstawić rangę poetów skupionych wokół almanachu „Ziewonia”, Ryszarda Berwińskiego czy nawet niektóre utwory Słowackiego. Dla zwycięstwa tezy Brodzińskiego decydujące znaczenie miała opinia Mickiewicza, który już w I kursie prelekcji paryskich powiedział: 
Walka między chrześcijaństwem a pogaństwem [...] toczy się nadal w całej literaturze słowiańskiej; wielu słowianofilów dotknęło tej sprawy. W swoim przywiązaniu do starożytności własnej ojczyzny atakują chrześcijaństwo. [...]

Przedstawia się je jako religię nową i gwałtem narzuconą Słowianom. Można temu zaprzeczyć. Chrześcijaństwo nie powinno było być uważane za nowość, bo nie przychodziło niszczyć dawnych tradycji, ale rosło w siły tym, co je wykładało i wypełniało. To właśnie tłumaczy jego postępy. (Mickiewicz 8: 135)

Oryginalność Norwidowskiej refleksji na ten temat wynika przede wszystkim z ciągłego konfrontowania słowiańskości z chrześcijańskim uniwersalizmem. Takie naczelne wartości, jak nadzieja, wolność, miłość, są przez pisarza rozważane w perspektywie egzystencjalnej, religijnej, moralnej, a dopiero na drugim planie politycznej. Analiza wątku słowiańskiego w całej twórczości Norwida: od misteriów dramatycznych (Wanda, Krakus), poprzez wiersze z końca lat czterdziestych (Klątwy, Pieśń od ziemi naszej), późniejsze traktaty poetyckie (Niewola, Rzecz o wolności słowa [1869]), aż po późny wiersz Słowianin (1882) - odsłania drogę od nadziei historiozofa, któremu bliski jest słowiański mesjanizm do tonów autoironii podważających tę nadzieję (Halkiewicz-Sojak, „Norwidowski wariant”). Karol Wojtyła jako młody poeta podjął ten norwidowski trop, a kontynuował - także jako Jan Paweł II.

\section{WĄTKI SŁOWIAŃSKIE W PAPIESKIM NAUCZANIU}

Na wagę tego tematu zwracał uwagę Ryszard Łużny - slawista, uczestnik spotkania w Castel Gandolfo w 1996 roku. W swoich artykułach skupiał on uwagę na interpretacji encykliki Slavorum apostoli i wątkach, które od początku pontyfikatu Jana Pawła II prowadziły do jej opracowania (Łużny). Znamienna pod tym względem była pierwsza pielgrzymka do Polski w 1979 roku. Już u jej początku, w homilii wygłoszonej 3 czerwca na Wzgórzu Lecha w Gnieźnie Ojciec Święty kilkakrotnie podkreślił, że przybywa do ojczyzny jako papież - Słowianin. Czytelna aluzja do profetycznego wiersza Słowackiego nie była tutaj literackim ozdobnikiem, lecz formułą ujmującą sens całej pasterskiej wizyty. Jan Paweł II podkreślał, że przybył do Polaków, ale także do „pobratymczych narodów”, by je „przygarnąć do serca Kościoła" (Jan Paweł II, Pielgrzymki 37, 38) i odsłonić profetyczny sens ich dziejów. Na kolejnych przystankach szlaku pielgrzyma unaoczniał, że historię tej części Europy można czytać jako szczególne świadectwo Krzyża, Zmartwychwstania i działania Ducha Świętego.

Kontynuacją refleksji nad miejscem Słowian na duchowej mapie kontynentu był list apostolski Egregiae virtutis z 31 grudnia 1980 roku, w którym papież ogłosił Cyryla i Metodego patronami Europy, obok św. Benedykta. W ten sposób zwrócił 
uwagę na drugie, obok zachodniego - wschodnie skrzydło chrześcijańskiego dziedzictwa oraz na wspólne źródła obu. List zapowiadał poniekąd czwartą encyklikę Jana Pawła II - Slavorum apostoli, poświęconą misji Braci Sołuńskich.

Dzięki misjonarskim wysiłkom obu Świętych ludy słowiańskie mogły sobie po raz pierwszy uświadomić własne powołanie do uczestnictwa w odwiecznym planie Przenajświętszej Trójcy, w powszechnym planie zbawienia świata. Poznały w ten sposób swój wkład w dobro całej historii ludzkości stworzonej przez Boga Ojca, odkupionej przez Syna Zbawiciela i oświeconej przez Ducha Świętego. (Jan Paweł II, „Slavorum apostoli” 239)

Wyraźny jest w tej encyklice misjonizm (Walicki) jako postawa historiozoficzna oraz podkreślenie, że to przede wszystkim kultura konstytuuje narody predestynowane do wypełniania swojej roli w dziejach świata. Mirosława Ołdakowska-Kuflowa zwróciła uwagę, że chociaż w encyklikach Jana Pawła II są obecne cechy stylu artystycznego, to nie pojawia się literatura jako sproblematyzowany temat. Wyjątek stanowi encyklika Slavorum apostoli (Ołdakowska-Kuflowa 95, 96), bo mowa tu o świętości, która ujawniła się w charyzmacie „literackim” - przekładzie Pisma na język starosłowiański i stworzeniu przy okazji tego tłumaczenia pierwszego języka literackiego Słowian. Anastazja Seul, analizując papieskie homilie wygłaszane podczas pielgrzymek do krajów słowiańskich, dowiodła, że odwołania do kultury literackiej odwiedzanych narodów były stałym elementem duszpasterskiego przekazu (Seul, „Odwołania do kultury”). Tak było jednak nie tylko w Bułgarii, Chorwacji czy na Ukrainie, ale przede wszystkim na polskich szlakach. W Polsce Jan Paweł II wskazywał idee polskiego romantyzmu, a także wykraczających poza romantyzm: Norwida i Wyspiańskiego, by odsłonić źródła polskiego posłannictwa we współczesnej Europie. To posłannictwo miało polegać na rechrystianizacji przestrzeni społecznej i na odnowieniu wartości zagubionych w zachodnim sekularyzmie. Z drugiej strony - miało ono wskazywać drogę do moralno-politycznego ładu narodom naszej części Europy. Początek realizacji tego procesu dostrzegał Papież w ruchu „Solidarności” i dawał temu wyraz w homiliach, najmocniej bodaj w Gdańsku na Zaspie w 1987 roku. Ta metapolityczna idea wyrastała z tradycji romantycznego mesjanizmu, jeśli rozumieć ten nurt myśli tak szeroko, jak zaproponowali to ostatnio Michał Sokulski („Echa”) czy Paweł Rojek (Liturgia). Ten ostatni autor uznał, że jest to taki zespół historiozoficznych idei, w którym splatają się (w różnych proporcjach) trzy nurty: millenaryzm, misjonizm i poszukiwanie sensu cierpienia (pasjonizm). Tak rozumiany mesjanizm niesie projekt pokojowej przemiany szanującej godność człowieka. Przyjmowaliśmy te idee z entuzjazmem do 1990 roku, ale ich przypomnienie w trakcie papieskiej pielgrzymki w 1991 roku zostało głosami kształtującej się wówczas opiniotwórczej elity gwałtownie odrzucone (Szarek). Papież skonstatował z goryczą: „Kiedy podczas ostatnich odwiedzin w Polsce wybrałem jako temat 
homilii Dekalog oraz przykazanie miłości, wszyscy polscy zwolennicy programu oświeceniowego poczytali mi to za złe" (Jan Paweł II, Pamięć i tożsamość 60). Może w tamtym odrzuceniu tkwi głęboka przyczyna obecnego aksjologicznego zamętu i nadszedł czas, by powrócić do źródeł papieskiego przesłania?

\section{BIBLIOGRAFIA}

Bernacki, Marek. „Słowiańska Pieśń Miłości - o funkcji poety i poezji w Sonetach - Zarysach Karola Wojtyły”. Karol Wojtyła - poeta, red. Jacek Głażewski i Witold Sadowski, Wydawnictwa Uniwersytetu Warszawskiego, 2006, ss. 171-178.

Brodziński, Kazimierz. Pisma estetyczno-krytyczne, t. 1, oprac. Zbigniew J. Nowak, Ossolineum, 1964. Burek, Tomasz. „«A wszystko jest dziełem Łaski»; Gra z cieniem”, [przedruk z: Dziennik kwarantanny, 2001]. Pisarstwo Karola Wojtyly - Jana Pawła II w oczach krytyków i uczonych. Antologia, oprac. Krzysztof Dybciak, PIW, 2019, ss. 174-177.

Burghart, Marta. „Poezje młodzieńcze Karola Wojtyły: analiza tekstologiczna”. Karol Wojtyła - poeta, red. Jacek Głażewski i Witold Sadowski, Wydawnictwa Uniwersytetu Warszawskiego, 2006, ss. 77-82.

Dołęga Chodakowski, Zorian [wł. Adam Czarnocki]. O Stawiańszczyźnie przed chrześcijaństwem oraz inne pisma i listy, oprac. Julian Maślanka, PWN, 1967.

Dybciak, Krzysztof. Karol Wojtyła a literatura. Biblos, 1991.

Dybciak, Krzysztof. „Wprowadzenie”. Pisarstwo Karola Wojtyły - Jana Pawła II w oczach krytyków i uczonych. Antologia, oprac. Krzysztof Dybciak, PIW, 2019.

Dziedzic, Stanisław. „Pieśń nie przebrzmiała. Juwenilia Karola Wojtyły”. Przestrzeń słowa. Twórczość literacka Karola Wojtyły - Jana Pawła II, red. Jan Machniak i Zofia Zarębianka, Wydawnictwo Uniwersytetu Jagiellońskiego, 2006, ss. 31-49.

Halkiewicz-Sojak, Grażyna. „Autokreacja w Promethidionie”. Studia Norwidiana, 9/10, 1991/92, ss. $27-44$.

Halkiewicz-Sojak, Grażyna. Nawiązane ogniwo. Studia o poezji Cypriana Norwida i jej kontekstach. Wydawnictwo Naukowe Uniwersytetu Mikołaja Kopernika, 2010.

Halkiewicz-Sojak, Grażyna. „Norwidowski wariant tematu słowiańskiego na romantycznym tle”. Studia Norwidiana, 31, 2013, ss. 17-39.

Herder, Johann Gottfried. Wybór pism, oprac. Tadeusz Namowicz, BN II/222, Ossolineum, 1987.

Jan Paweł II. Pamięć i tożsamość. Rozmowy na przełomie tysiącleci. Znak, 2005.

Jan Paweł II. Pielgrzymki do Ojczyzny. Przemówienia i homilie. Znak, 2012.

Jan Paweł II. „Slavorum apostoli”. Encykliki Ojca Świętego Jana Pawła II. Znak, 2000, ss. 215-252. Janion, Maria. „Kres paradygmatu”. Rzeczpospolita, nr 63, 1992.

Janion, Maria. Niesamowita Stowiańszczyzna. Wydawnictwo Literackie, 2016.

Klarnerówna, Zofia. Stowianofilstwo w literaturze polskiej lat 1800-1848. Warszawa, 1926.

Kozłowska, Anna. Od psalmów słowiańskich do rzymskich medytacji. O stylu artystycznym Karola Wojtyly. Wydawnictwo Uniwersytetu Kardynała Stefana Wyszyńskiego, 2013.

Krasiński, Zygmunt. „Psalmy przyszłości”. Dzieła zebrane, red. Mirosław Strzyżewski, t. 2: Poematy, oprac. Maciej Szargot, Wydawnictwo Naukowe UMK, 2017, ss. 159-238.

Krzemińska, Magdalena. „Synteza różnych kategorii i wzorów kultury we wczesnych sonetach Karola Wojtyły". Karol Wojtyła - poeta, red. Jacek Głażewski i Witold Sadowski, Wydawnictwa Uniwersytetu Warszawskiego, 2006, ss. 157-164. 
Łużny, Ryszard. Myśl stowiańska Jana Pawła II. Zbiór artykułów, oprac. Jan Orłowski, Anna Woźniak, Wydawnictwo KUL, 2008.

Maciejewski, Jarosław. „Karol Wojtyła i Jan Paweł II wobec literatury”, [przedruk z miesięcznika $W$ drodze, nr 7, 8, 1983]. Pisarstwo Karola Wojtyły - Jana Pawła II w oczach krytyków i uczonych. Antologia, oprac. Krzysztof Dybciak, PIW, 2019, ss. 116-146.

Mickiewicz, Adam. Dzieła, t. 8: Literatura słowiańska. Kurs pierwszy. Tłum. Leon Płoszewski, oprac. Julian Maślanka, „Czytelnik”, 1998.

Miłosz, Czesław. „O autonomii polskiej literatury”. Tygodnik Powszechny, nr 18, 2002.

Miłosz, Czesław. Prywatne obowiazki. Wydawnictwo Pojezierze, 1990.

Miłosz, Czesław. Rok myśliwego. Znak, 1991.

Norwid, Cyprian. Pisma wszystkie, oprac., wstępem i uwagami krytycznymi opatrzył Juliusz Wiktor Gomulicki, t. 1-11, PIW, 1971-1976.

Norwid, Cyprian. Promethidion. Rzecz w dwóch dialogach z epilogiem, oprac. i wstępem opatrzył Stefan Sawicki, „Biblioteka Polska”, Universitas, 1997.

Ołdakowska-Kuflowa, Mirosława. „Literackość w encyklikach Jana Pawła II”. Scripta Humana. Zeszyty Naukowe Uniwersytetu Zielonogórskiego, t. 10, 2018, ss. 95-113.

Pismo Święte Starego i Nowego Testamentu (Biblia Warszawsko-Praska), w przekładzie z języków oryginalnych opracował biskup Kazimierz Romaniuk, 1997.

Piwińska, Marta. Juliusz Słowacki od Duchów. Wydawnictwo Pen, 1992.

Popiel, Jacek. „, Karol Wojtyła i Mieczysław Kotlarczyk. Historia artystycznej przyjaźni”. Pisarstwo Karola Wojtyty - Jana Pawła II w oczach krytyków i uczonych. Antologia, oprac. Krzysztof Dybciak, PIW, 2019, ss, 502-518.

Popiel, Jacek. Los artysty w czasach zniewolenia. Teatr Rapsodyczny 1941-1967, Wydawnictwo Uniwersytetu Jagiellońskiego, 2006.

Rojek, Paweł. Liturgia dziejów. Jan Paweł II i polski mesjanizm, Biblioteczka „Pressji”, Wydawnictwo M, 2016.

Sawicki, Stefan. „Wstęp”. C. Norwid. Promethidion, „Biblioteka Polska”, Universitas, 1997.

Seul, Anastazja. Literatura polska w wypowiedziach Jana Pawła II: sacrum, prawda, dobro, piękno, Wydawnictwo Uniwersytetu Adama Mickiewicza, 2014.

Seul, Anastazja. „Odwołania do kultury literackiej narodów słowiańskich podczas pielgrzymek Jana Pawła II do krajów Europy Środkowej”. Scripta Humana. Zeszyty Naukowe Uniwersytetu Zielonogórskiego, t. 10, 2018, ss. 115-129.

Skwarnicki, Marek. „Poetycka droga papieża Wojtyły”. Wstęp. Karol Wojtyła. Poezje, dramaty, szkice. Jan Paweł II. Tryptyk rzymski. Znak, 2004, ss. 5-22.

Słowacki, Juliusz. Dzieła, red. Juliusz Kleiner, t. VII, Ossolineum, 1952.

Sokulski, Michał. „Echa mesjanizmów sarmackiego i romantycznego w wizji polskich dziejów Karola Wojtyły (Jeremiasz)/ Jana Pawła II (homilie z pielgrzymek do Ojczyzny)”. Karol Wojtyła/Jan Pawet II wobec tradycji kultury polskiej, red. Grażyna Halkiewicz-Sojak, Agnieszka Komorowska, Bartłomiej Łuczak, Michał Sokulski, Wydawnictwo Naukowe UMK, 2015, ss. 209-232.

Szarek, Jarosław. „Niechciana katecheza”. Dekalog dla Polaków, Dom Wydawniczy „Rafael”, 2006, ss. 6-35.

Szymański, Wiesław Paweł. „Zakorzenienie” [fragmenty książki Z mroku korzeni. (O poezji Karola Wojtyty). Kalwaria Zebrzydowska 1989]. Pisarstwo Karola Wojtyly - Jana Pawła II w oczach krytyków i uczonych. Antologia, oprac. Krzysztof Dybciak, PIW, 2019, ss. 156-173.

Urbanowski, Maciej. „«Widma lepszych świtań»: Renesansowy psatterz Karola Wojtyły a poezja pokolenia wojennego". Karol Wojtyła - poeta, red. Jacek Głażewski i Witold Sadowski, Wydawnictwa Uniwersytetu Warszawskiego, 2006, ss. 13-32.

Walicki, Andrzej. Mesjanizm Adama Mickiewicza w perspektywie porównawczej. IBL PAN; IFiS PAN, 2006. 
Witkowska, Alina. , Ja, glupi Stowianin”, „Biblioteka Romantyczna”, Wydawnictwo Literackie, 1980. Wojtyła, Karol. „Słowo wstępne”. Słowa na pustyni. Antologia współczesnej poezji kapłańskiej, Oficyna Poetów i Malarzy, 1971, ss. 4-6.

Wojtyła, Karol. Poezje i dramaty. Wybór i układ Marek Skwarnicki i Jerzy Turowicz, Znak, 1979. Wojtyła, Karol. Poezje, dramaty, szkice. Jan Paweł II. Tryptyk rzymski. Wstęp Marek Skwarnicki, Znak, 2004.

\section{TEMAT SŁOWIAŃSKI W TWÓRCZOŚCI LITERACKIEJ I PRZESŁANIU PASTORALNYM KAROLA WOJTYŁY - JANA PAWŁA II}

\section{Streszczenie}

Punktem wyjścia jest w artykule pytanie: Czy istnieje związek między tematem słowiańskim we wczesnej poezji Karola Wojtyły a papieskim nauczaniem Jana Pawła II skierowanym do narodów słowiańskich? Rozpoznaniu głównych inspiracji i idei obecnych w juweniliach Wojtyły służy analiza trzech aspektów jego poezji: kreacji podmiotu, literackich pokrewieństw z wyboru oraz ewokowanych idei historiozoficznych. Wynik komparatystycznego badania wskazuje na zakorzenienie poetyckiej wyobraźni Autora przede wszystkim w Biblii i w twórczości polskich poetów romantycznych. Szczególnie uprzywilejowane miejsce zajmuje tutaj Cyprian Norwid jako autor poematów Promethidion i Fortepian Szopena. Koncepcja narodów i ich dziejowej misji ma i w poezji, i w nauczaniu papieskim liczne punkty wspólne z myślą słowiańską Adama Mickiewicza (prelekcje paryskie) i Norwida. Świadczą o tym wątki wybranych homilii oraz encyklika Slavorum apostoli.

Słowa kluczowe: poezja Karola Wojtyły; wątek słowiański; Słowiańszczyzna a chrześcijaństwo; historiozofia polskiego romantyzmu; Cyprian Norwid; Jan Paweł II; encyklika Slavorum apostoli

\section{THE SLAVIC THEME IN THE LITERARY WORKS AND PASTORAL MESSAGES OF KAROL WOJTYŁA / JOHN PAUL II}

\section{Su m mary}

The starting point of this article is the question of whether there is a connection between the Slavic theme in the early poetry of Karol Wojtyła and the papal teaching of John Paul II addressed to the Slavic nations. The main inspirations and ideas present in Wojtyla's juvenilia are identified through the analysis of three aspects of his poetry: the creation of the subject, the literary kinship by choice and the historiosophical ideas evoked. The results of this comparative research indicates that the author's poetic imagination is rooted primarily in the Bible and in the works of the Polish Romantic poets. A particularly privileged place here is occupied by Cyprian Norwid, the author of the poems Promethidion and Chopin's Piano. The concept of nations and their historical mission in the papal teaching has numerous points in common with the Slavic thoughts of Adam Mickiewicz (in his Paris lectures) and Norwid in his poetry. The threads of selected homilies and the encyclical Slavorum Apostoli testify to this.

Keywords: Karol Wojtyła's poetry; Slavic thread; Slavicism and Christianity; historiosophy of Polish

Romanticism; Cyprian Norwid; John Paul II; encyclical Slavorum Apostoli 